ISSN 1678-3921

Journal homepage: www.embrapa.br/pab

For manuscript submission and journal contents, access: www.scielo.br/pab

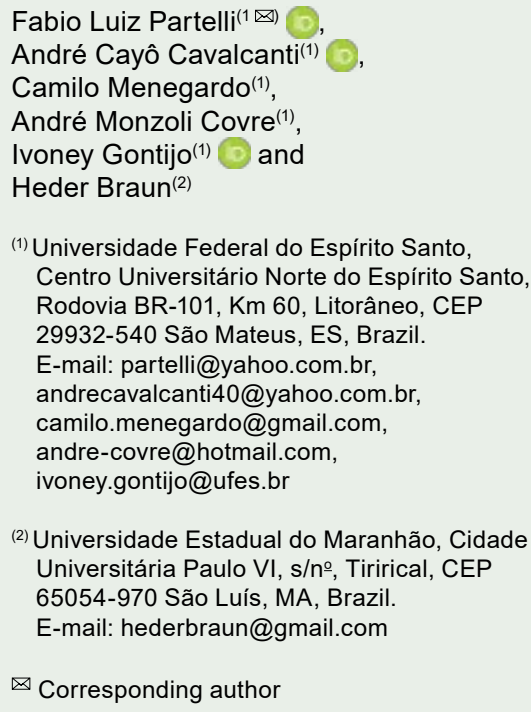

(2) Universidade Estadual do Maranhão, Cidade Universitária Paulo VI, s/no, Tirirical, CEP 65054-970 São Luís, MA, Brazil. E-mail: hederbraun@gmail.com

$\bowtie$ Corresponding author

Received

March 9, 2019

Accepted

January 31, 2020

How to cite

PARTELLI, F.L; CAVALCANTI, A.C.

MENEGARDO, C.; COVRE, A.M.; GONTIJO, I.; BRAUN, H. Spatial distribution of the root system of Conilon and Arabica coffee plants. Pesquisa Agropecuária Brasileira, v.55, e01333, 2020. DOI: https://doi.org/10.1590/ S1678-3921.pab2020.v55.01333.

\section{Spatial distribution of the root system of Conilon and Arabica coffee plants}

\begin{abstract}
The objective of this work was to evaluate the root system of Conilon coffee (Coffea canephora) and Arabica coffee (Coffea arabica) plants in the soil profile, using semivariograms. The evaluations were carried out in an area located in the municipality of Jaguaré, in the state of Espírito Santo, Brazil. The Verdebrás G30/G35 Conilon coffee and the Catuaí Vermelho IAC 44 Arabica coffee cultivars were assessed. Soil monoliths with coffee plant roots were collected at three distances from the trunk in the planting row and at six distances from the trunk between rows, at six depths. The roots were collected and washed and then digitized and processed in the Safira software. The spatial variability of the evaluated attributes was characterized by the geostatistical technique, through semivariograms, using the GS+7.0 software. Root surface area, length, and volume were quantified for the two coffee species. Conilon coffee plants have a tendency of showing a root system with a smaller surface area, shorter length, and lower volume by volume of soil, as well as a less discrepant distribution on soil surface and in deeper layers, compared with Arabica coffee.
\end{abstract}

Index terms: Coffea arabica, Coffea canephora, semiovariogram, soil profile.

\section{Distribuição espacial do sistema radicular de plantas de café conilon e arábica}

Resumo - O objetivo deste trabalho foi avaliar o sistema radicular de plantas de café conilon (Coffea canephora) e café arábica (Coffea arabica) no perfil do solo, com uso de semivariogramas. As avaliações foram realizadas em área localizada no município de Jaguaré, no estado do Espírito Santo. Foram avaliadas as cultivares Verdebrás G30/G35 do café conilon e a Catuaí Vermelho IAC 44 do café arábica. Monólitos de solo com raízes de café foram coletados em três distâncias do tronco do cafeeiro, no sentido da linha, e em seis distâncias do tronco, no sentido da entrelinha de plantio, em seis níveis de profundidade. As raízes foram coletadas e lavadas e, depois, digitalizadas e processadas no programa Safira. A variabilidade espacial dos atributos avaliados foi caracterizada pela técnica geoestatística, por meio de semivariogramas, com uso do programa GS+ 7.0. A área de superfície, o comprimento e o volume das raízes foram quantificados para as duas espécies de café. O café conilon tem tendência de apresentar sistema radicular com menor área superficial, comprimento e volume de raízes por volume de solo, bem como com distribuição menos discrepante na superfície do solo e em profundidade, em comparação ao café arábica.

Termos para indexação: Coffea arabica, Coffea canephora, semivariograma, perfil do solo. 


\section{Introduction}

Among coffee varieties, Arabica (Coffea arabica L.) and Conilon (Coffea canephora Pierre ex A.Froehner) coffee stand out as the most economically important. Arabica coffee represents about $63 \%$ of the coffee marketed worldwide. This species is indigenous to the highlands of Ethiopia, former Abyssinia, and is currently grown in the Americas, Africa, and Asia. Arabica coffee has a quality superior to that of the others, with marked aroma and sweet taste, and is widely consumed around the world, purely or in mixtures with other coffee species (Ribeiro et al., 2014).

Conilon coffee is indigenous to the lowland forests of Equatorial Africa, in the Congo River Basin, and is currently cultivated in some central and western African countries, southeastern Asia, and South America. Conilon coffee is commonly used in the preparation of blend mixtures with Arabica coffee, compounding up to $30 \%$ of the final product, and, since it has a higher soluble solid contents and a higher yield after the roasting process than Arabica coffee, it is an essential component of soluble coffee (Ribeiro et al., 2014). The main characteristics of most Conilon coffee genotypes are: tolerance to high temperatures, soil water uptake efficiency, stomatal control, and leaf area reduction to maintain perspiration (Pinheiro et al., 2004; Marraccini et al., 2012; Silva et al., 2013).

Genotypes with a relatively high production are able to maintain an adequate leaf water potential when subjected to water deficit, by deepening their root system and also increasing stomatal control (Silva et al., 2010). This shows the importance of the root system for an efficient and sustainable crop management, since root development, combined with soil and climate factors, can improve nutrient absorption and directly affect yield and tolerance to water deficit (Partelli et al., 2014; Ronchi et al., 2015).

Root system characteristics may vary, depending on plant species, genotype, and age, as well as on season of the year, climate, crop density, root diameter, biotic stresses, soil texture and structure, and crop management (Partelli et al., 2014; Covre et al., 2015; Ronchi et al., 2015). In the case of Arabica coffee cultivation, which has recently increased in lower altitude areas, with a predominance of higher temperatures, a diversification of plant properties has been observed under these conditions (Partelli et al., 2014).

Therefore, studies on the structures and functions of root systems are fundamental for understanding the performance of cultivated plants. Varying results have been reported for coffee plant root systems regarding root distribution in the soil profile, physiology, size, and volume (Carvalho et al., 2008; Partelli et al., 2014; Ronchi et al., 2015). The main challenges in these researches is the great amount of work and time required to measure root length, volume, area, and diameter. Moreover, according to Himmelbauer et al. (2002), the used methods include errors that may limit the obtained results.

Geostatistical techniques, such as the semivariogram with the aid of digitalized image analysis systems, have facilitated the study of the root systems of coffee plants (Partelli et al., 2014; Covre et al., 2015; Ronchi et al., 2015), with faster and more accurate measurements to evaluate root characteristics such as length, surface area, diameter, and size.

The objective of this work was to evaluate the root system of Conilon coffee and Arabica coffee plants in the soil profile, using semivariograms.

\section{Materials and Methods}

The evaluations were carried out in a commercial area, in the municipality of Jaguaré, in the northwestern portion of the state of Espírito Santo, Brazil (1857'S, $40^{\circ} 18 \mathrm{~W}$, at approximately $150 \mathrm{~m}$ altitude). The region has a tropical climate, with a hot and a humid summer and a dry winter according to Köppen-Geiger's classification; an annual average precipitation of 1,200 $\mathrm{mm}$; and an annual average temperature of $23^{\circ} \mathrm{C}$, with a minimum of $18^{\circ} \mathrm{C}$ and a maximum of $29^{\circ} \mathrm{C}$ (Alvares et al., 2013; ANA, 2016). The soil of the experimental area is a Latossolo Amarelo (Santos et al., 2013), i.e., an Oxisol, which was originally dystrophic, with a sandy loam texture. Subsoiling, plowing, and harrowing were performed for the implementation of the coffee crop in the area.

The Conilon coffee seedlings were obtained from three orthotropic sprout cuttings of the Verdebrás G30/G35 cultivar (Verdebrás Biotecnologia, Linhares, ES, Brazil). The seedlings of Arabica coffee were produced from the Catuaí Vermelho IAC 44 cultivar 
(Instituto Agronômico, Campinas, SP, Brazil) through one cutting.

The seedlings of both genotypes were planted at a spacing of 3.0x1.5 m, grown in full sun, and irrigated by a fixed sprinkler system. Cultural practices were carried out according to the technical recommendations for coffee crops (Matiello, 1998; Ferrão et al., 2017), using the same amounts of fertilizers.

For evaluation, soil monoliths with roots $\left(27 \mathrm{~cm}^{3}\right.$ volume) were collected in eight experimental units, at three trunk distances from the planting row $(0.25$, 0.50 , and 0.75 ) and at six trunk distances between rows $(0.25,0.50,0.75,1.0,1.25$, and $1.50 \mathrm{~m})$, in six soil layers $(0.00-0.10,0.10-0.20,0.20-0.30,0.30-0.40$, $0.40-0.50$, and $0.50-0.60 \mathrm{~m}$ ), using a probe auger. Extra soil samples were taken for the chemical and granulometric characterization of the soil profile (Table 1). The design was completely randomized, in split plot, with four replicates.

The collected samples were packed in plastic bags and kept in a cold room at approximately $-10^{\circ} \mathrm{C}$ until they were washed under running water in a 30-mesh sieve, to separate the roots. The roots were then digitized with an 18.2 megapixel digital camera and analyzed in the Safira software (Jorge \& Rodrigues, 2008). Root surface area $\left(\mathrm{mm}^{2} \mathrm{~cm}^{-3}\right)$, length $\left(\mathrm{mm} \mathrm{cm}^{-3}\right)$, volume $\left(\mathrm{mm}^{3} \mathrm{~cm}^{-3}\right)$ per volume of soil, and diameter $(\mathrm{mm})$ were quantified.

Since root surface area, length, and volume presented no normal distribution, they were transformed by the function $y=\log (x+11)$. The data obtained after the Box-Cox transformation were subjected to the analysis of variance, and means were compared by Tukey's test, at 5\% probability, using the Assistat software, version 7.7 beta (Silva \& Azevedo, 2002).

The spatial variability of the evaluated attributes was characterized using a geostatistical technique, the semivariogram (Vieira et al., 1983), based on the assumption of the stationarity of the intrinsic hypothesis, which was estimated by the equation:

$$
\gamma(\mathrm{h})=\frac{\sum_{\mathrm{i}=1}^{\mathrm{n}(\mathrm{h})}\left[\mathrm{z}\left(\mathrm{x}_{\mathrm{i}}+\mathrm{h}\right)-\mathrm{z}\left(\mathrm{x}_{\mathrm{i}}\right)\right]^{2}}{2 \mathrm{n}(\mathrm{h})} \int
$$

where $\gamma(\mathrm{h})$ is the semiovariogram function, $\mathrm{n}(\mathrm{h})$ is the number of sample pairs $\left[\mathrm{z}\left(\mathrm{x}_{\mathrm{i}}\right) ; \mathrm{z}\left(\mathrm{x}_{\mathrm{i}}+\mathrm{h}\right)\right]$ separated by vector $h$, and $z\left(x_{i}\right)$ and $z\left(x_{i}+h\right)$ are the observed numerical values of the analyzed attribute for points $x_{i}$ and $x_{i}+h$ separated by vector $h$.

The geostatistical analysis was performed using the GS+ 7.0 software (Robertson, 2008). The

Table 1. Chemical and textural properties of the studied Oxisol, a Latossolo Amarelo, at six depths, when planted with crops of the Verdebrás G30/G35 Conilon coffee (Coffea canephora) cultivar and the Catuaí Vermelho IAC 44 Arabica coffee (Coffea arabica) cultivar, in the municipality of Jaguaré, in the state of Espírito Santo, Brazil.

\begin{tabular}{|c|c|c|c|c|c|c|}
\hline \multirow[t]{2}{*}{ Variable } & \multicolumn{6}{|c|}{ Soil depth $(\mathrm{cm})$} \\
\hline & $0-10$ & $10-20$ & $20-30$ & $30-40$ & $40-50$ & $50-60$ \\
\hline $\mathrm{P}\left(\mathrm{mg} \mathrm{dm}^{-3}\right)$ & 65.0 & 18.0 & 10.0 & 7.0 & 10.0 & 11.0 \\
\hline $\mathrm{K}\left(\mathrm{mg} \mathrm{dm} \mathrm{m}^{-3}\right)$ & 160.0 & 220.0 & 210.0 & 190.0 & 150.0 & 110.0 \\
\hline $\mathrm{S}\left(\mathrm{mg} \mathrm{dm}^{-3}\right)$ & 9.0 & 17.0 & 8.0 & 10.0 & 11.0 & 8.0 \\
\hline $\mathrm{Ca}\left(\mathrm{cmol}_{\mathrm{C}} \mathrm{dm}^{-3}\right)$ & 3.0 & 2.5 & 2.2 & 1.5 & 1.5 & 1.3 \\
\hline $\operatorname{Mg}\left(\mathrm{cmol}_{\mathrm{c}} \mathrm{dm}^{-3}\right)$ & 0.5 & 0.4 & 0.3 & 0.2 & 0.2 & 0.2 \\
\hline $\mathrm{Al}\left(\mathrm{cmol}_{\mathrm{c}} \mathrm{dm}^{-3}\right)$ & 0.0 & 0.0 & 0.0 & 0.1 & 0.11 & 0.2 \\
\hline $\mathrm{H}+\mathrm{Al}\left(\mathrm{cmol}_{\mathrm{c}} \mathrm{dm}^{-3}\right)$ & 2.6 & 2.1 & 1.9 & 2.4 & 2.5 & 2.8 \\
\hline $\mathrm{pH}$ & 5.7 & 5.9 & 6.0 & 5.6 & 5.6 & 5.5 \\
\hline Organic matter $\left(\right.$ dag $\left.\mathrm{kg}^{-1}\right)$ & 3.1 & 2.6 & 2.1 & 1.9 & 1.8 & 1.5 \\
\hline $\mathrm{Fe}\left(\mathrm{mg} \mathrm{dm}^{-3}\right)$ & 54.0 & 102.0 & 133.0 & 177.0 & 151.0 & 173.0 \\
\hline $\mathrm{Zn}\left(\mathrm{mg} \mathrm{dm}^{-3}\right)$ & 6.7 & 4.3 & 2.3 & 1.3 & 1.4 & 1.5 \\
\hline $\mathrm{Cu}\left(\mathrm{mg} \mathrm{dm}^{-3}\right)$ & 0.1 & 0.10 & 0.1 & 0.1 & 0.1 & 0.1 \\
\hline $\operatorname{Mn}\left(\mathrm{mg} \mathrm{dm}^{-3}\right)$ & 26.0 & 19.0 & 12.0 & 5.0 & 5.7 & 6.0 \\
\hline $\mathrm{B}\left(\mathrm{mg} \mathrm{dm}^{-3}\right)$ & 0.97 & 0.85 & 0.91 & 0.81 & 0.67 & 0.71 \\
\hline $\mathrm{Na}\left(\mathrm{mg} \mathrm{dm}^{-3}\right)$ & 69.0 & 85.0 & 84.0 & 82.0 & 62.0 & 48.0 \\
\hline
\end{tabular}


semivariograms were fitted by testing the spherical, exponential, and Gaussian theoretical models, and their parameters nugget effect $\left(\mathrm{C}_{\mathrm{o}}\right)$, landing $(\mathrm{C})$, plateau $\left(\mathrm{C}_{\mathrm{o}}+\mathrm{C}\right)$, and range were determined. To choose among more than one model for the same semivariogram, the highest value of the correlation coefficient obtained by the cross-validation method was considered (Amado et al., 2007).

The spatial dependence index (SDI) showed the percentage ratio of the $\mathrm{C}_{\mathrm{o}}$ in relation to the $\mathrm{C}_{\mathrm{o}}+\mathrm{C}$ and was evaluated by the equation:

$$
\mathrm{SDI}=\frac{\mathrm{C}_{\mathrm{o}}}{\mathrm{C}_{\mathrm{o}}+\mathrm{C}} 100 \mathrm{f}
$$

The SDIs were classified as: strong, $\leq 25 \%$; moderate, 25 to $75 \%$; and weak, $\geq 75 \%$ (Cambardella et al., 1994). Kriging was done using the Surfer software (Golden Software, LLC), developing maps of variables from the spatial distribution data.

All the studied attributes fitted the spherical model (Table 2), which is the most used by researchers to describe semivariograms of soil and plant attributes (Salviano et al., 1998). The initial selection of the best model considered mainly: the smallest residual sum of squares (RSS), the highest coefficient of determination of the fitted model, and the highest values of the cross-validation regression coefficient between actual and estimated data. Cross-validation was used to validate the fitted semivariogram models for kriging; according to Faraco et al. (2008), among the criteria for the validation of soil attributes, cross-validation is the most appropriate method to choose the best fitting model.

\section{Results and Discussion}

According to the kriging analysis, all the root variables of the two coffee species presented spatial dependence, with semivariograms fitted to the spherical and exponential models (Figure 1).

The cross-validation coefficients ranged from 0.760 to 1.095 , which indicates that the adequate fitting represented the spatial characteristic of the evaluated attributes. The RSS was also used as a parameter for the choice of the model to be used. According to Robertson (1998), RSS is a more robust parameter and provides a more accurate measure of the model that fits the data. A SDI lower than $25 \%$ was found for all studied variables (Table 2), which shows a high degree of spatial dependence.

Root surface area, length, and volume tend to increase, especially in Arabica coffee, with decreasing horizontal distances from the trunk, both in the planting row and between rows, in the first layers of the soil. These three characteristics, however, decrease with increasing distances between coffee tree trunks, mainly in the region between rows, and with increasing soil depths (Figures 2, 3, and 4). Ronchi et al. (2015) found similar results, observing a greater root surface area, length, volume, and dry matter in regions closer to the trunk of full-grown Arabica coffee. Similarly, Partelli et al. (2014) reported a greater root surface area, length, and volume between rows of Conilon coffee at 146 months of age, in a densified system, confirming the results of the present study.

Although the development of the coffee plant root system is predominately related to plant genetics, other factors can affect its spatial distribution, such as

Table 2. Models and estimated parameters of the experimental semivariograms for the studied variables of the Verdebrás G30/G35 Conilon coffee (Coffea canephora) cultivar and the Catuaí Vermelho IAC 44 Arabica coffee (Coffea arabica) cultivar, in the municipality of Jaguaré, in the state of Espírito Santo, Brazil.

\begin{tabular}{|c|c|c|c|c|c|c|}
\hline \multirow[t]{2}{*}{ Variable $^{(1)}$} & \multicolumn{2}{|c|}{ Length $\left(\mathrm{mm} \mathrm{cm}^{-3}\right)$} & \multicolumn{2}{|c|}{ Volume $\left(\mathrm{mm}^{2} \mathrm{~cm}^{-3}\right)$} & \multicolumn{2}{|c|}{ Surface area $\left(\mathrm{mm}^{2} \mathrm{~cm}^{-3}\right)$} \\
\hline & Arabica & Conilon & Arabica & Conilon & Arabica & Conilon \\
\hline SDI & 24.72 & 10.03 & 23.08 & 24.68 & 24.46 & 24.84 \\
\hline $\mathrm{R}^{2}$ & 0.992 & 0.997 & 0.979 & 0.977 & 0.990 & 0.994 \\
\hline RSS & $1.1 \times 10^{6}$ & $7.7 \times 10^{5}$ & $8.0 \times 10^{6}$ & $2.7 \times 10^{7}$ & $5.4 \times 10^{8}$ & $5.2 \times 10^{8}$ \\
\hline $\mathrm{RCV}$ & 0.884 & 0.875 & 0.760 & 1.095 & 0.877 & 1.086 \\
\hline
\end{tabular}

${ }^{(1)} \mathrm{SDI}$, spatial dependency index; $\mathrm{R}^{2}$, coefficient of determination; RSS, value of the residual sum of the mean square; and RCV, cross-validation regression coefficient. 
propagation type, seedling formation, and, especially, soil water content (Partelli et al., 2013, 2014). In the deepest soil layers, low fertility may be a limiting factor for the development of the coffee root system in Brazil (Covre et al., 2015). Therefore, topdressing fertilization is also an important factor since it can be
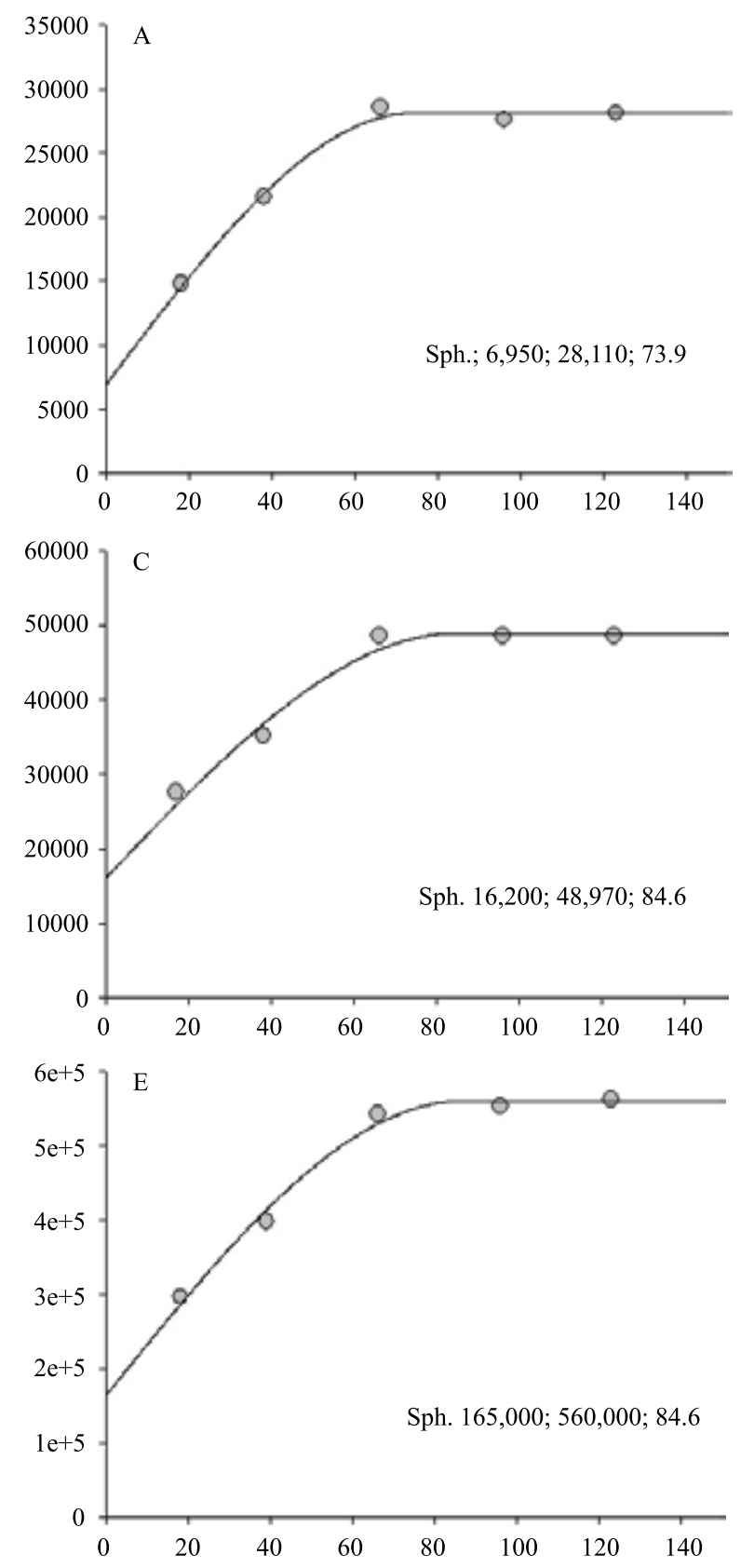

applied in the planting rows, where there is a higher concentration of roots from 10 to $50 \mathrm{~cm}$ from the trunk, reaching up to $75 \mathrm{~cm}$.

Conilon coffee plant roots tend to have a smaller surface area, shorter length, and lower volume per soil volume, as well as a less discrepant distribution on the
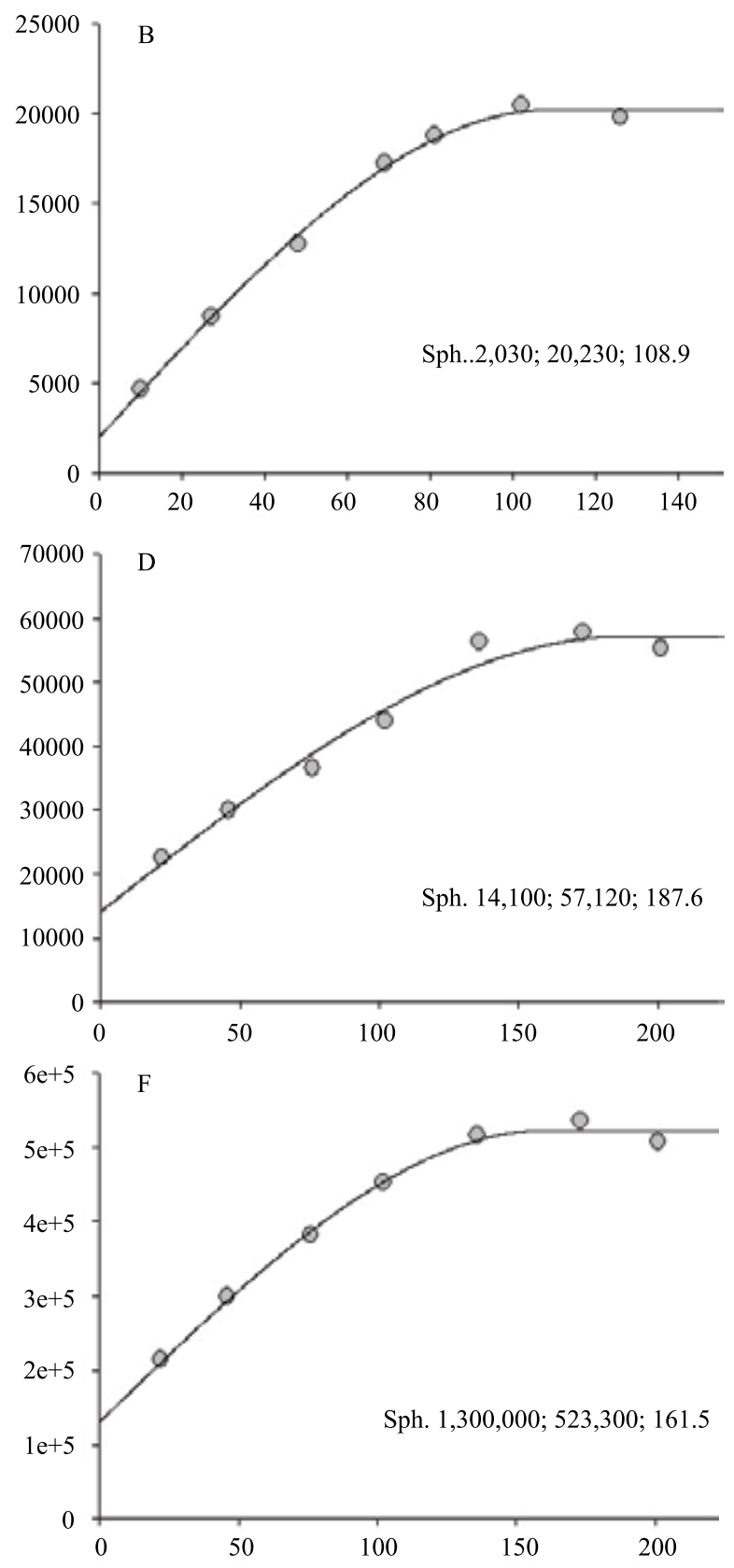

Figure 1. Semivariogram of the root length (A), volume (B), and surface area (C) of plants of the Catuaí Vermelho IAC 44 Arabica coffee (Coffea arabica) cultivar, as well as root length (D), volume (E), and surface area (F) of plants of the Verdebrás G30/G35 Conilon coffee (Coffea conilon) cultivar, in the municipality of Jaguaré, in the state of Espírito Santo, Brazil. Values described in each semivariogram are: nugget effect, plateau, and range, respectively. Sph, spherical model. 
soil surface and in deeper layers, when compared with those of Arabica coffee (Figures 2, 3, and 4). Regarding the spatial distribution of the root length of Arabica coffee plants (Figure 3), a significant concentration of roots was observed in deeper soil layers. This denotes an important characteristic associated with water deficit tolerance, frequent in low-altitude regions. A similar result was found by Rodrigues et al. (2001), Motta et al. (2006), and Sakai et al. (2015), while evaluating the root system distribution of Arabica coffee plants along the soil profile.

The volume of the root system of Conilon coffee on soil surface layers tends to be larger than that of Arabica coffee (Figure 4), which may be due to fertilizer applications to the soil surface, explaining the absence of a more prominent pivot root (Covre et al., 2015). The vegetative propagation of Conilon coffee to maintain the genetic characteristics of the parent plant also allows the crop to show homogeneity regarding grain maturation (early, middle, or late) and other desirable characteristics (Weigel \& Jürgens, 2002). In addition, the vegetative propagation of this coffee species by cuttings has the advantage of a precocious initial production (Partelli et al., 2014). Currently, Conilon coffee is planted using seedlings from cuttings originating from orthotropous branches (Partelli et al., 2014; Covre et al., 2015; Ronchi et al., 2015), as performed in the present work (Figures 2, 3, and 4).

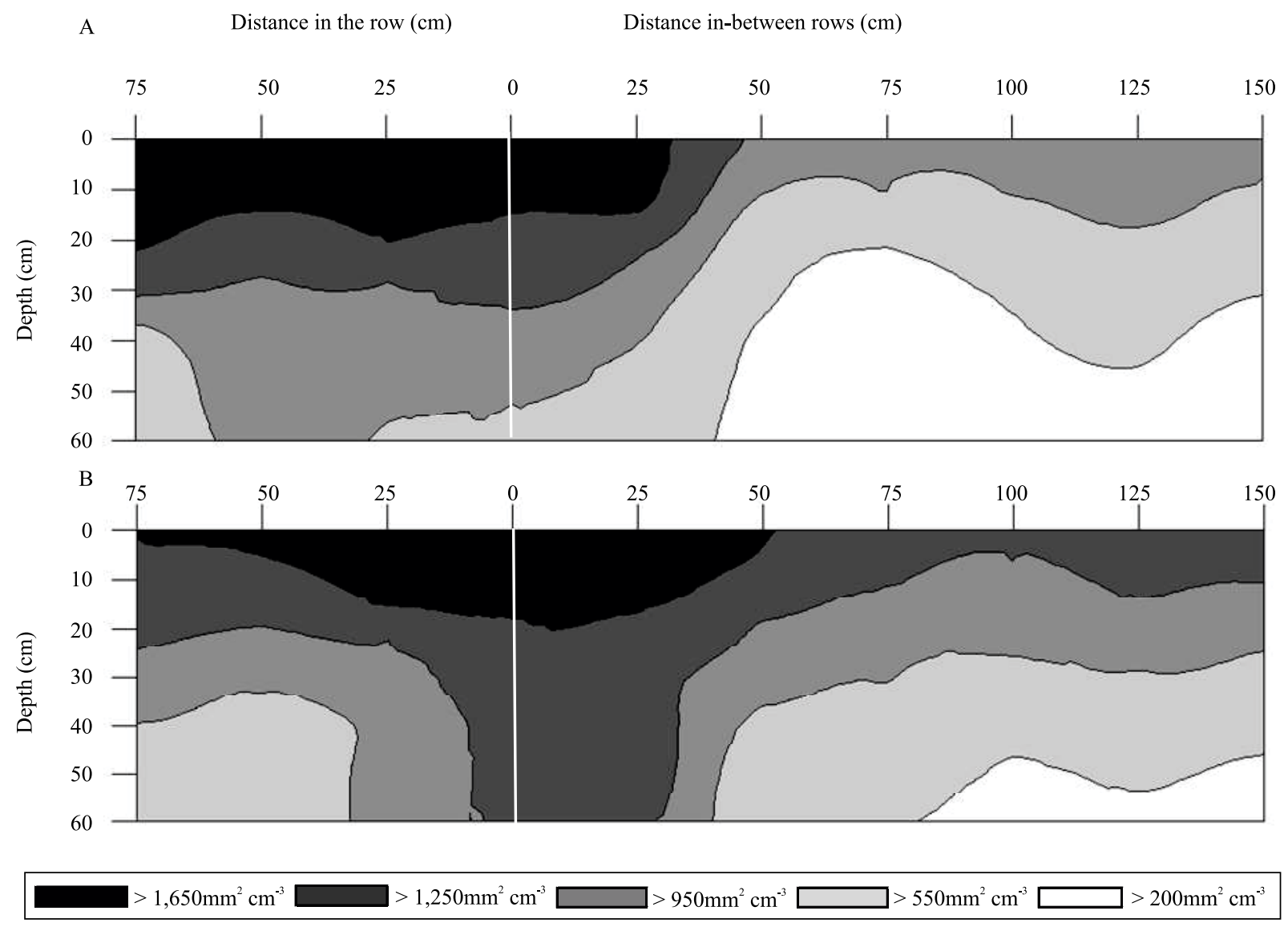

Figure 2. Spatial distribution of the root surface area of plants of the Verdebrás G30/G35 Conilon coffee (Coffea canephora) cultivar (A) and the Catuaí Vermelho IAC 44 Arabica coffee (Coffea arabica) cultivar (B), at different distances and depths, in the municipality of Jaguaré, in the state of Espírito Santo, Brazil. The zero point refers to the location of the plant. 


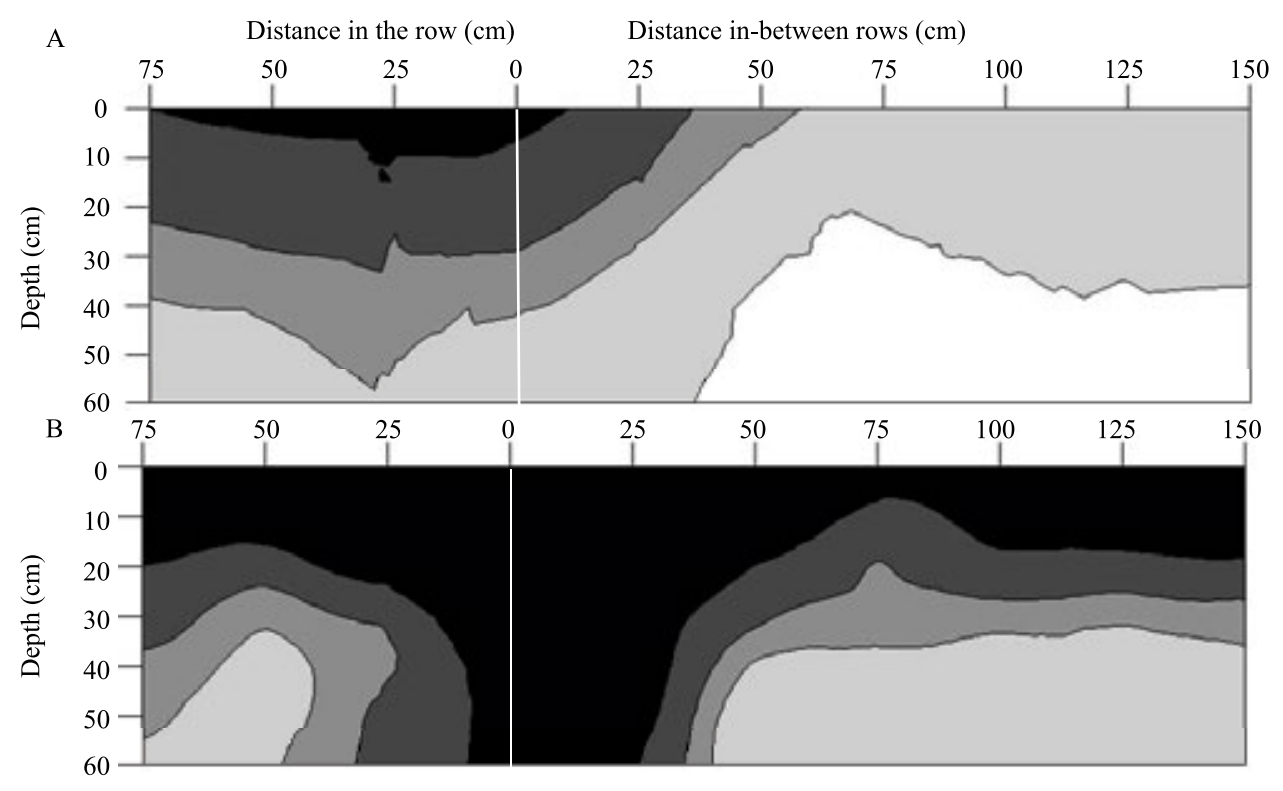

Figure 3. Spatial distribution of root length of plants of the Verdebrás G30/G35 Conilon coffee (Coffea canephora) cultivar (A) and of the Catuaí Vermelho IAC 44 Arabica coffee (Coffea arabica) cultivar (B), at different distances and depths, in the municipality of Jaguaré, in the state of Espírito Santo, Brazil. The zero point refers to the location of the plant.

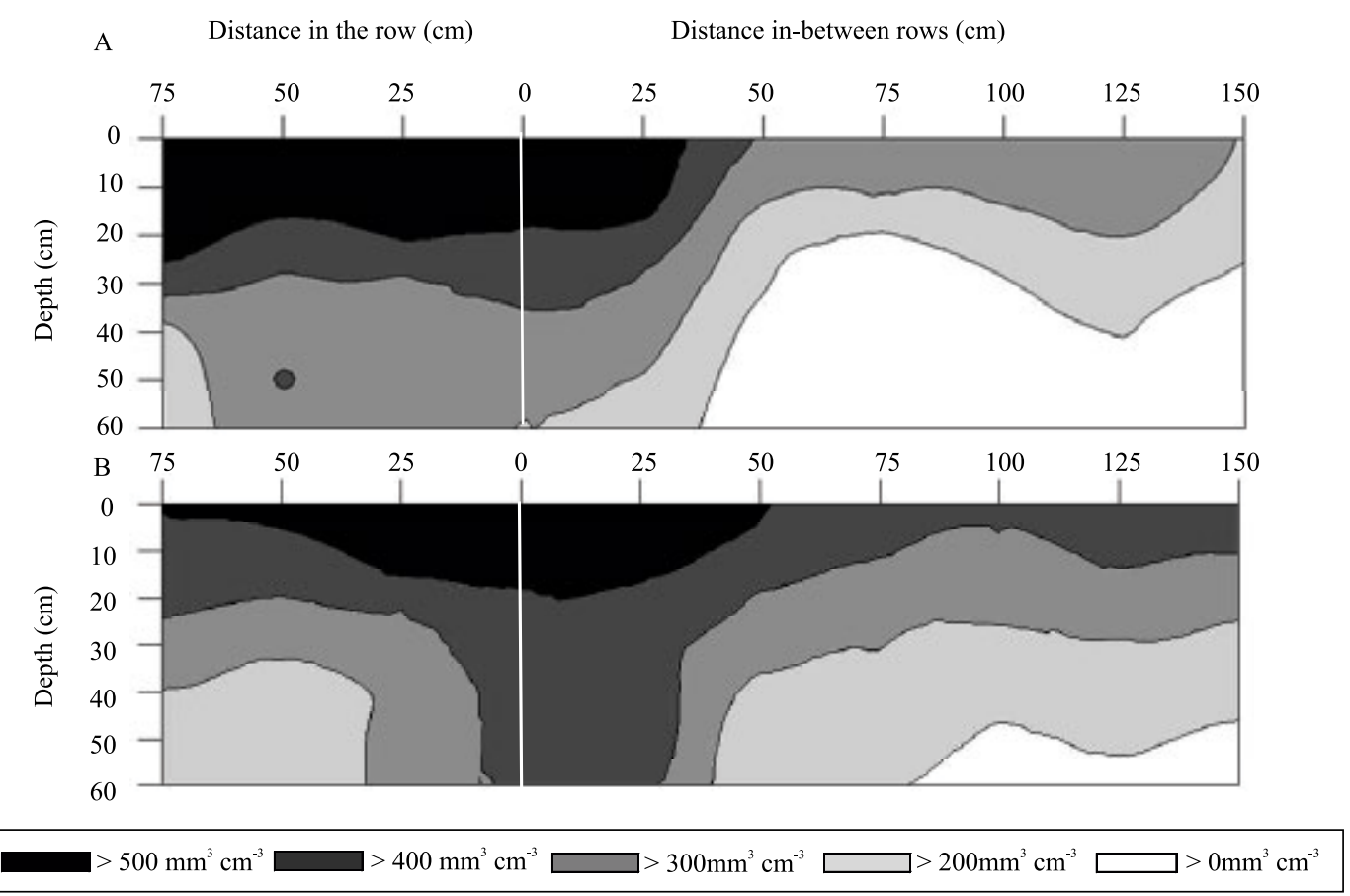

Figure 4. Spatial distribution of the root volume of plants of the Verdebrás G30/G35 conilon coffee (Coffea canephora) cultivar (A) and the Catuaí Vermelho IAC 44 Arabica coffee (Coffea arabica) cultivar (B), at different distances and depths, in the municipality of Jaguaré, in the state of Espírito Santo, Brazil. The zero point refers to the location of the plant. 


\section{Conclusions}

1. The root system of Conilon coffee (Coffea canephora) plants differs from that of Arabica coffee (Coffea arabica), tending to show a smaller surface area, shorter length, and lower volume by volume of soil, as well as a less discrepant distribution on soil surface and in deeper layers.

2. The semivariogram, with the aid of the Safira digitized image analysis system, is efficient in evaluating the root system of both coffee genotypes evaluated.

\section{Acknowledgments}

To Conselho Nacional de Desenvolvimento Científico e Tecnológico (CNPq), for support.

\section{References}

ALVARES, C.A.; STAPE, J.L.; SENTELHAS, P.C.; MORAES, J.L. de M.; SPAROVEK, G. Köppen's climate classification map for Brazil. Meteorologische Zeitschrift, v.22, p.711-728, 2013. DOI: https://doi.org/10.1127/0941-2948/2013/0507.

AMADO, T.J.C.; PONTELLI, C.B.; SANTI, A.L.; VIANA, J.H.M.; SULZBACH, L.A. de S. Variabilidade espacial e temporal da produtividade de culturas sob sistema de plantio direto. Pesquisa Agropecuária Brasileira, v.42, p.1101-1110, 2007. DOI: https://doi.org/10.1590/S0100-204X2007000800006.

ANA. Agência Nacional de Águas. A bacia do Rio Doce: características da bacia. Available at: $<$ http://www.ana.gov.br/ cbhriodoce/bacia/caracterizacao.asp\#clima>. Accessed on: Dec. 52016.

CAMBARDELLA, C.A.; MOORMAN, T.B.; NOVAK, J.M.; PARKIN, T.B.; KARLEN, D.L.; TURCO, R.F.; KONOPKA, A.E. Field-scale variability of soil properties in central Iowa soils. Soil Science Society of America Journal, v.58, p.1501-1511, 1994. DOI: https://doi.org/10.2136/sssaj1994.03615995005800050033x.

CARVALHO, M.; JESUS, A.M.S.; CARVALHO, S.P. de; GOMES, C.N.; SOARES, A.M. Comportamento em condições de campo de cafeeiros (Coffea arabica L.) propagados vegetativamente e por semeadura. Coffee Science, v.3, p.108-114, 2008.

COVRE, A.M.; PARTELLI, F.L.; GONTIJO, I.; ZUCOLOTO, M. Distribuição do sistema radicular de cafeeiro conilon irrigado e não irrigado. Pesquisa Agropecuária Brasileira, v.50, p.1006-1016, 2015. DOI: https://doi.org/10.1590/S0100-204X2015001100003.

FARACO, M.A.; URIBE-OPAZO, M.A.; SILVA, E.A.A. da; JOHANN, J.A.; BORSSOI, J.A. Seleção de modelos de variabilidade espacial para elaboração de mapas temáticos de atributos físicos do solo e produtividade da soja. Revista Brasileira de Ciência do Solo, v.32, p.463-476, 2008. DOI: https://doi.org/10.1590/S0100-06832008000200001.
FERRÃO, R.G.; FONSECA, A.F.A. da; FERRÃO, M.A.G.; DE MUNER, L.H. (Ed.). Café Conilon. 2.ed. atual. e ampl. Vitória: Incaper, 2017. 784p.

HIMMELBAUER, M.; LOISKANDL, W.; KASTANEK, F. Estimation of root morphological characteristics using Images analyses systems. In: WORLD CONGRESS OF SOIL SCIENCE, 17., 2002, Bangkok. Soil science: confronting new realities in the $21^{\text {st }}$ century: proceedings. Bangkok: [s.n.], 2002. p.14-21.

JORGE, L.A. de C.; RODRIGUES, A.F. de O. Safira: sistema de análise de fibras e raízes. São Carlos: Embrapa Instrumentação Agropecuária, 2008. 20p. (Embrapa Instrumentação Agropecuária. Boletim de pesquisa e desenvolvimento, 24).

MARRACCINI, P.; VINECKY, F.; ALVES, G.S.C.; RAMOS, H.J.O.; ELBELT, S.; VIEIRA, N.G.; CARNEIRO, F.A.; SUJII, P.S.; ALEKCEVETCH, J.C.; SILVA, V.A.; DAMATTA, F.M.; FERRÃO, M.A.G.; LEROY, T.; POT, D.; VIEIRA, L.G.E.; SILVA, F.R. da; ANDRADE, A.C. Differentially expressed genes and proteins upon drought acclimation in tolerant and sensitive genotypes of Coffea canephora. Journal of Experimental Botany, v.63, p.4191-4212, 2012. DOI: https://doi.org/10.1093/jxb/ ers103.

MATIELLO, J.B. Café conilon: como plantar, tratar, colher, preparar e vender. Rio de Janeiro: Procafé, 1998. 162p.

MOTTA, A.C.V.; NICK, J.A.; YORINORI, G.T.; SERRAT, B.M. Distribuição horizontal e vertical da fertilidade do solo e das raízes de cafeeiro (Coffea arabica L.) cultivar Catuaí. Acta Scientiarum. Agronomy, v.28, p.455-463, 2006. DOI: https://doi. org/10.4025/actasciagron.v28i4.758.

PARTELLI, F.L.; COVRE, A.M.; OLIVEIRA, M.G.; ALEXANDRE, R.S.; VITÓRIA, E.L. da; SILVA, M.B. da. Root system distribution and yield of 'Conilon' coffee propagated by seeds or cuttings. Pesquisa Agropecuária Brasileira, v.49, p.349-355, 2014. DOI: https://doi.org/10.1590/S0100$204 X 2014000500004$.

PARTELLI, F.L.; MARRÉ, W.B.; FALQUETO, A.R.; VIEIRA, H.D.; CAVATTI, P.C. Seasonal vegetative growth in genotypes of Coffea canephora, as related to climatic factors. Journal of Agricultural Science, v.5, p.108-116, 2013. DOI: https://doi. org/10.5539/jas.v5n8p108.

PINHEIRO, H.A.; DAMATTA, F.M.; CHAVES, A.R.M.; FONTES, E.P.B.; LOUREIRO, M.E. Drought tolerance in relation to protection against oxidative stress in clones of Coffea canephora subjected to long-term drought. Plant Science, v.167, p.1307-1314, 2004. DOI: https://doi.org/10.1016/j.plantsci.2004.06.027 1308.

RIBEIRO, B.B.; MENDONÇA, L.M.V.L.; ASSIS, G.A.; MENDONÇA, J.M.A. de; MALTA, M.R.; MONTANARI, F.F. Avaliação química e sensorial de blends de Coffea canephora Pierre e Coffea arabica L. Coffee Science, v.9, p.178-186, 2014.

ROBERTSON, G.P. GS+: geostatistics for the environmental sciences. Plainwell: Gamma Design Software, 2008.

ROBERTSON, G.P. GS+ geostatistics for the environmental sciences: GS+ users guide. Plainwell: Gamma Design Software, 1998. 152p. 
RODRIGUES, L.A.; MARTINEZ, H.E.P.; NEVES, J.C.L.; NOVAIS, R.F.; MENDONÇA, S.M. Growth response of coffee tree shoots and roots to subsurface liming. Plant and Soil, v.234, p.207-214, 2001. DOI: https://doi.org/10.1023/A:1017999318532.

RONCHI, C.P.; SOUSA JÚNIOR, J.M. de; AMEIDA, W.L. de; SOUZA, D.S.; SILVA, N.O.; OLIVEIRA, L.B. de; GUERRA, A.M.N. de M.; FERREIRA, P.A. Morfologia radicular de cultivares de café arábica submetidas a diferentes arranjos espaciais. Pesquisa Agropecuária Brasileira, v.50, p.187-195, 2015. DOI: https://doi.org/10.1590/S0100-204X2015000300001.

SAKAI, E.; BARBOSA, E.A.A.; SILVEIRA, J.M. de C.; PIRES, R.C. de M. Coffee productivity and root systems in cultivation schemes with different population arrangements and with and without drip irrigation. Agricultural Water Management, v.148, p.16-23, 2015. DOI: https://doi.org/10.1016/j.agwat.2014.08.020.

SALVIANO, A.A.C.; VIEIRA, S.R.; SPAROVEK, G. Variabilidade espacial de atributos de solo e de Crotalaria juncea L. em área severamente erodida. Revista Brasileira de Ciência do Solo, v.22, p.115-122, 1998. DOI: https://doi.org/10.1590/ S0100-06831998000100016.

SANTOS, H.G. dos; JACOMINE, P.K.T.; ANJOS, L.H.C. dos; OLIVEIRA, V.A. de; LUMBRERAS, J.F.; COELHO, M.R.; ALMEIDA, J.A. de; CUNHA, T.J.F.; OLIVEIRA, J.B. de. Sistema brasileiro de classificação de solos. 3.ed. rev. e ampl. Brasília: Embrapa, 2013. 353p.
SILVA, F. de A.S. e; AZEVEDO, C.A.V. de. Versão do programa computacional Assistat para o sistema operacional Windows. Revista Brasileira de Produtos Agroindustriais, v.4, p.71-78, 2002.

SILVA, P.E.M.; CAVATTE, P.C.; MORAIS, L.E.; MEDINA, E.F.; DAMATTA, F.M. The functional divergence of biomass partitioning, carbon gain and water use in Coffea canephora in response to the water supply: implications for breeding aimed at improving drought tolerance. Environmental and Experimental Botany, v.87, p.49-57, 2013. DOI: https://doi.org/10.1016/j. envexpbot.2012.09.005.

SILVA, V.A.; ANTUNES, W.C.; GUIMARÃES, B.L.S.; PAIVA, R.M.C.; SILVA, V. de F.; FERRÃO, M.A.G.; DAMATTA, F.M.; LOUREIRO, M.E. Resposta fisiológica de clone de café Conilon sensível à deficiência hídrica enxertado em porta-enxerto tolerante. Pesquisa Agropecuária Brasileira, v.45, p.457-464, 2010. DOI: https://doi.org/10.1590/S0100-204X2010000500004.

VIEIRA, S.R.; HATFIELD, J.L; NIELSEN, D.R; BIGGAR, J.W. Geostatistical theory and application to variability of some agronomical properties. Hilgardia, v.51, p.1-75, 1983. DOI: https://doi.org/10.3733/hilg.v51n03p075.

WEIGEL, D.; JÜRGENS, G. Stem cells that make stems. Nature, v.415, p.751-754, 2002. DOI: https://doi.org/10.1038/415751a. 